\title{
130. Unsaturated Fatty Acids and Their Derivatives.
}

\author{
Part XI. The Configuration of Eruco- and Brassido- \\ dibromo-behenic Acid.
}

By Tsutomu MaruYama.

Institute for Chemical Research, Kyoto Imperial University.

(Comm. by U. Suzuki, M.I.A., Oct. 12, 1934.)

Erucic acid was isolated from rape seed oil following Kimura's Method $^{1)}$ as an acid potassium soap (m.p : $108-110^{\circ} \mathrm{C}$, I. V. (Wijs') 70.4 (calc. as $\mathrm{C}_{22} \mathrm{H}_{41} \mathrm{O}_{2} \mathrm{~K} \cdot \mathrm{C}_{22} \mathrm{H}_{42} \mathrm{O}_{2}: 70.3$ )). The free acid has been recovered from the soap solution by extracting with ether after the solution was acidified with $\mathrm{HCl}\left(\mathrm{m} . \mathrm{p}: 33^{\circ} \mathrm{C}\right.$ ). The methylester of the erucic acid was oxidized with $\mathrm{KMnO}_{4}{ }^{2}$ ) and pelargonic acid (as $\mathrm{Zn}$-salt m.p : $131^{\circ} \mathrm{C}$, $\mathrm{ZnO}: 21.14$ (calc. : 22.43)) and brassylic acid (m.p: $112^{\circ} \mathrm{C}, \mathrm{C}: 63.90$, $\mathrm{H}: 9.50$ (calc. $\mathrm{C}: 63.88, \mathrm{H}: 9.91$ )) had been separated. The result justifies the constitution of erucic acid commonly assigned, that is, docosan-13-monoen-22-acid.

Docosan-8-monoen-10-bromo-22-acid (III). Erucic acid was brominated in ethereal solution to prepare dibromo-acid (m.p: $43^{\circ} \mathrm{C}, \mathrm{Br}$ : 31.89 (calc. 32.08$)$ ). The dibromo-behenic acid $(10 \mathrm{~g})$ was treated with calculated amount of alcoholic potash to eliminate one half of bromine atom as $\mathrm{HBr}$ at $80^{\circ} \mathrm{C}$. After 10 hours the reaction mixture was extracted with ether after being acidified with $\mathrm{HCl}$, and the crystalline monobromo-acid had been obtained (yield: $7.2 \mathrm{~g}$ (calc.: $8.3 \mathrm{~g}$ ), m.p : $33^{\circ} \mathrm{C}$, m.w. calc. from acid value : 410.3 (calc. 417.25 ), $\mathrm{Br}: 19.08$ (calc. 19.15)). The methylester of the monobromo-acid was oxidized and caprylic acid ( $\mathrm{Zn}$-salt m.p: $135^{\circ} \mathrm{C}, \mathrm{ZnO}: 23.11$ (calc. 23.14)) and tetradeca-2-hydroxy-1 : 14-diacid (m.p : $108^{\circ} \mathrm{C}, \mathrm{C}: 61.23, \mathrm{H}: 9.86$ (calc. $\mathrm{C}: 61.71, \mathrm{H}: 9.56)$ ) were obtained. Accordingly the constitution III is assigned to the acid.

Docosan-8 : 10-dien-22-acid (IV). Eruco-dibromo-behenic acid (5 g) was heated at $80^{\circ} \mathrm{C}$ for 3 hours with alcoholic potash $(\mathrm{KOH}: 3 \mathrm{~g}$, alcohol: $42 \mathrm{cc}$ ), the mixture was acidified and extracted with ether. From the ethereal solution, behenolic acid (yield: $0.8 \mathrm{~g}$ ) and a new

1) W. Kimura: J. Soc. Ind. Japan, 32 (1929), 895.

2) Armstrong and Hilditch: J. Soc. Chem. Ind., 44 (1925), 180. This method adopted in the study exclusively for the oxidation. 
acid (yield : $1.1 \mathrm{~g}, \mathrm{m.p}: 63^{\circ} \mathrm{C}, \mathrm{H}_{2}$-value : 130 (calc. : 133.1 ), m.w. from acid value: 338.08 (calc. as $\mathrm{C}_{22} \mathrm{H}_{40} \mathrm{O}_{2}: 336.32$ ), $\mathrm{C}: 78.22, \mathrm{H}: 12.82$ (calc. C: 78,56, H: 12.00)) have been separated out. The methylester $(5 \mathrm{~g})$ of the new acid was oxidized and Ca-oxalate (yield: $1.8 \mathrm{~g}$ ), $\mathrm{Zn}$ caprylate (yield : $1.1 \mathrm{~g}, \mathrm{m.p}: 135^{\circ} \mathrm{C}, \mathrm{ZnO}: 23.33$ ) and dodeca-1:10diacid (yield : $2.7 \mathrm{~g}$, m.p : $125^{\circ} \mathrm{C}, \mathrm{C}: 62.50, \mathrm{H}: 9.09$ (calc. as $\mathrm{C}_{12} \mathrm{H}_{22} \mathrm{O}_{4}$ $\mathrm{C}: 62.56, \mathrm{H}: 9.64)$ ) have been isolated, the results of which prove that the acid should have the constitution IV.

Behenolic acid V. To docosan-8:10-dien-22-acid $(1 \mathrm{~g})$, alcoholic potash $(\mathrm{KOH}: 0.6 \mathrm{~g}$, alcohol: $4 \mathrm{cc})$ was added and the mixture was heated at $150^{\circ} \mathrm{C}$ for 8 hours. From the ether extract, behenolic acid was isolated (m.p: $57^{\circ} \mathrm{C}$ ). On the other hand, behenolic acid had been prepared by the usual method. Both the specimens were mixed but the m.p. did not show the sign of depression. The constitution of behenolic acid was reaffirmed by the oxidation method obtaining Zn-pelargonate (m.p : $131^{\circ} \mathrm{C}, \mathrm{ZnO}:$ 21.24) and brassylic acid (m.p : $\left.112^{\circ} \mathrm{C}, \mathrm{C}: 63.19, \mathrm{H}: 10.60\right)$.

From the results thus shown, it is obvious that behenolic acid is formed from eruco-dibromo-behenic acid by passing through the following stages:

\begin{tabular}{|c|c|c|c|c|}
\hline $\begin{array}{l}\mathrm{CH}_{3} \\
\left(\mathrm{CH}_{2}\right)_{6} \\
\mathrm{HCH}\end{array}$ & 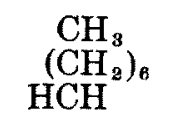 & $\begin{array}{l}\mathrm{CH}_{3} \\
\left(\mathrm{CH}_{2}\right)_{6}\end{array}$ & $\begin{array}{l}\mathrm{CH}_{3} \\
\left(\mathrm{CH}_{2}\right)_{6}\end{array}$ & $\begin{array}{l}\mathrm{CH}_{3} \\
\left(\mathrm{CH}_{2}\right)_{6} \\
\mathrm{HCH}\end{array}$ \\
\hline $\mathrm{CH}$ & $\mathrm{BrCH}$ & $\stackrel{\|}{\mathrm{C}} \mathrm{H}$ & $\stackrel{\|}{\mathrm{C}} \mathrm{H}$ & C \\
\hline $\mathrm{CH}$ & $\mathrm{BrCH}$ & $\mathrm{BrCH}$ & $\mathrm{CH}$ & C \\
\hline $\begin{array}{l}\mathrm{HCH} \\
\left(\mathrm{CH}_{3}\right)_{10} \\
\mathrm{COOH}^{-}\end{array}$ & $\begin{array}{l}\mathrm{HCH} \\
\left(\mathrm{CH}_{2}\right)_{10} \\
\mathrm{COOH}\end{array}$ & $\begin{array}{l}\mathrm{HCH} \\
\left(\mathrm{CH}_{2}\right)_{10} \\
\mathrm{COOH}\end{array}$ & $\begin{array}{l}\mathrm{CH} \\
\left(\mathrm{CH}_{2}\right)_{10} \\
\mathrm{COOH}\end{array}$ & $\begin{array}{c}\mathrm{HCH} \\
\left(\mathrm{CH}_{2}\right)_{20} \\
\mathrm{COOH}\end{array}$ \\
\hline I & $\mathrm{II}^{*}$ & III & IV & V \\
\hline
\end{tabular}

(* The enantiomorph of the construction was laid aside for simplicity.)

Brassido-dibromo-behenic acid VII. Brassidic acid (m.p : $59.5-60^{\circ} \mathrm{C}$, I.V : 74.2 (calc. : 75.00) VI prepared by the action of nitrous acid on erucic acid, was brominated in an ethereal solution (m.p: $53^{\circ} \mathrm{C}, \mathrm{Br}$ : 31.83).

Docosan-9-monoen-9- or 10-monobromo-22-acid VIII. Brassidodibromo-behenic acid $(10 \mathrm{~g})$ was heated with alcoholic potash (KOH: $6 \mathrm{~g}$, alcohol: $84 \mathrm{cc}$ ) at $80^{\circ} \mathrm{C}$ for 3 minutes. By extracting the acidified reaction mixture a crystalline substance (yield: $7.0 \mathrm{~g}, \mathrm{~m} . \mathrm{p}: 41^{\circ} \mathrm{C}, \mathrm{Br}$ : 19.10 (calc. as $\mathrm{C}_{22} \mathrm{H}_{41} \mathrm{BrO}_{2}: 19.15$ ), m.w. from acid value : 413.85 (calc.: 417.25)) has been obtained. 
The methylester of the acid Fig. 1.

was oxidized and $\mathrm{Zn}$-pelargonic acid (m.p : $131^{\circ} \mathrm{C}, \mathrm{ZnO}: 21.33$ ) and brassylic acid (m.p : $112^{\circ} \mathrm{C}$, $\mathrm{C}: 63.51, \mathrm{H}: 9.97$ ) was isolated so that the construction VIII is assigned to the acid. The elimination of $\mathrm{HBr}$ of this monobromo-acid is strikingly hard contradistinctly to the corresponding substance III of the erucic acid, heating at a much higher temperature

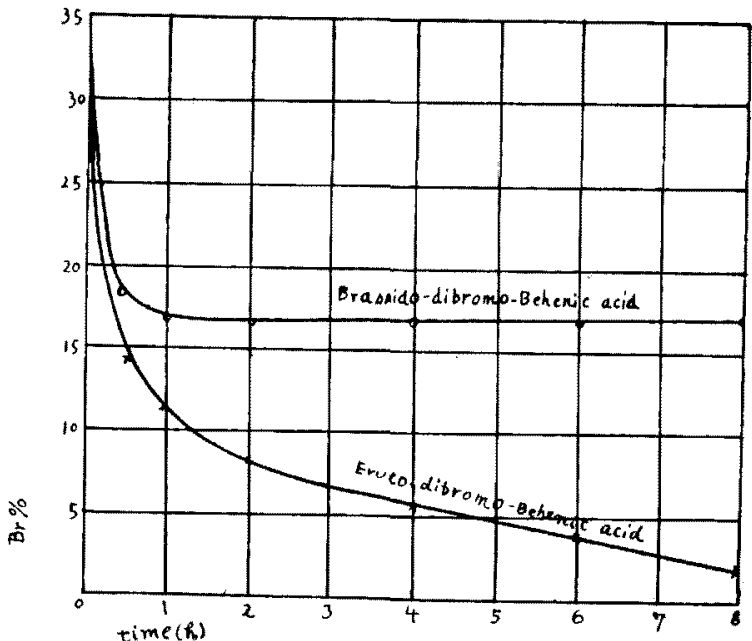
$\left(200^{\circ} \mathrm{C}\right)$ being necessary to complete the reaction (fig. 1).

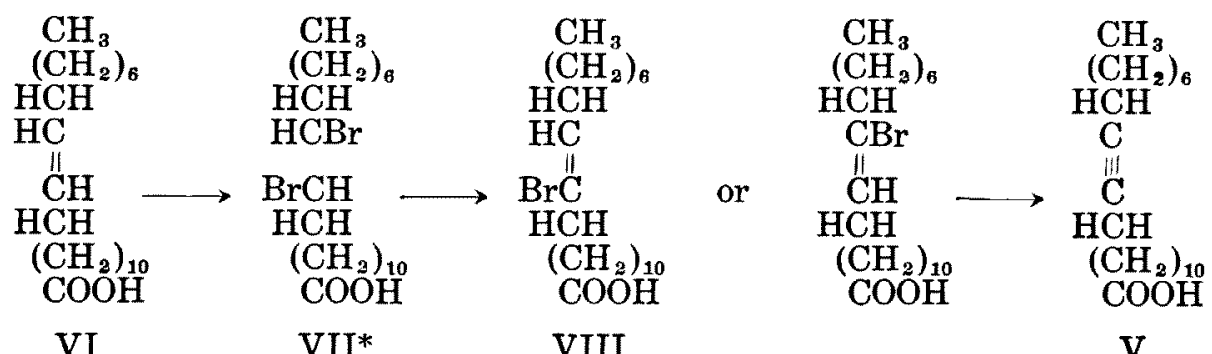

(* The enantiomorph of the acid is omitted for simplicity.)

How the construction II to eruco-dibromo-behenic acid and VII to brassido-dibromobehenic acid is given respectively, the work of $\mathrm{T}$. Maruyama and B. Suzuki is to be reffered to."

Comparing the results mentioned above with those obtained in the case of oleic and elaidic acid, we will notice that there exist striking similarities. And if we are to assume cis construction for oleic acid and trans for elaidic on the same reasoning basis, we should assign cis form for erucic and trans for brassidic.

The author expresses his cordial thanks to Prof. Bunsuke Suzuki under whose guidance this work has been carried out. A part of the expenses of the work was defrayed by the allowance endowed by the Imperial Academy and the Hattori-Hoko-kwai.

1) T. Maruyama and B. Suzuki: Proc. 7 (1931), 265 and 376. 